\title{
DETERMINATION OF ALKALINITY AND DISSOCIATION CONSTANTS OF HIGH SALINITY WATERS: USE OF F5BC TITRATION FUNCTION.
}

\author{
Cavalcanti, B.F. ${ }^{1^{*}}$, Agostinho, L.C.L. ${ }^{2}$ and Nascimento, L. $^{2}$ \\ ${ }^{1}$ Civil Engineering Department ${ }^{1}$ - Federal University of Campina Grande - UFCG \\ E-mail: bernardete.ufcg@gmail.com \\ ${ }^{2}$ Federal University of Paraiba, Materials Department, João Pessoa, PB.
}

\begin{abstract}
Measurements of parameters expressed in terms of carbonic species such as Alkalinity and Acidity of saline waters do not analyze the influence of external parameters to the titration such as Total free and associated Carbonic Species Concentration, activity coefficient, ion pairing formation and Residual Liquid Junction Potential in $\mathrm{pH}$ measurements. This paper shows the development of F5BC titration function based on the titrations developed by Gran (1952) for the carbonate system of natural waters. For practical use, samples of saline waters from Pocinhos reservoir in Paraiba were submitted to titration and linear regression analysis. Results showed that F5BC involves F1x and F2x Gran functions determination, respectively, for Alkalinity and Acidity calculations without knowing "a priori" the endpoint of the titration. F5BC also allows the determination of the First and Second Apparent Dissociation Constant of the carbonate system of saline and high ionic strength waters.
\end{abstract}

Keywords: Saline waters; Alkalinity; Dissociation constants.

\section{INTRODUCTION}

Surface waters and groundwaters in the Northeast semi - arid region of Brazil are classified as high ionic strength waters. These waters exhibit excess of salt concentration, high hardness and are supersaturated with calcium carbonate, $\mathrm{CaCO}_{3}$.

Total carbonic species concentration, CT in saline waters is represented by the sum of the carbonate species such as carbonic gas, $\mathrm{CO}_{2}$, total bicarbonate (where $\mathrm{T}$ refers to total concentrations; i.e., free species and ion pairing or associated species), $\mathrm{HCO}_{3 \mathrm{~T}}{ }^{-}$and total carbonate (free and associated species), $\mathrm{CO}_{3}{ }^{2-}$ T. The system $\mathrm{H}_{2} \mathrm{CO}_{3}{ }^{*}+$ $\mathrm{HCO}_{3 \mathrm{~T}}^{-}+\mathrm{CO}_{3}^{2-}$ (where $\mathrm{H}_{2} \mathrm{CO}_{3} *$ refers to the sum of carbonic acid and carbonic gas) is determined from $\mathrm{pH}$ electrometric measurement and from any parameter defined in terms of the carbonic species [9]. In practice, it is difficult to measure CT and, hence, it is defined Total Alkalinity in order to determine all carbonic species.

Equations for Alkalinity and Acidity are as follows (in calcium carbonate scale, $\mathrm{mg} / \mathrm{LCa}$ $\mathrm{CO}_{3}$ ):

$\mathrm{Alc}=-\mathrm{H}^{+}+\mathrm{HCO}_{3 \mathrm{~T}^{-}}^{-}+\mathrm{CO}_{3 \mathrm{~T}^{-2}}+\mathrm{OH}_{\mathrm{T}}$

$\mathrm{Ac}=\mathrm{H}_{2} \mathrm{CO}_{3} *+\mathrm{HCO}^{-}{ }_{3 \mathrm{~T}}+\mathrm{H}^{+}-\mathrm{OH}_{\mathrm{T}}^{-}$

Interrelationship between Alkalinity and Acidity mass parameters and $\mathrm{pH}$ is depicted by means of graphical representations such as CT versus $\mathrm{pH}$ diagram, mass diagram, Bjerrum diagram and Modified Caldwell - Lawrence diagram. In high salinity waters addition of $\mathrm{CO}_{2}$ is considered for Alkalinity determination. In this case $\mathrm{pH}$ 
depends on $\mathrm{CT}$ and ionic matrix of the solution (ion pairing) and the first dissociation constant must be known. The endpoint of titration known as the $\mathrm{H}_{2} \mathrm{CO}_{3}{ }^{*}$ equivalence point, $\mathrm{pHe} 1$ varies with CT and pk"1 (where p refers to the negative decimal logarithm). This point is given by (in molar scale):

$$
\left[\mathrm{H}^{+}\right]=+\left[\mathrm{HCO}_{3}^{-}\right]_{\mathrm{T}}+\mathrm{CO}_{3}{ }^{2-}{ }_{\mathrm{T}}+\mathrm{OH}_{\mathrm{T}}^{-}
$$

From the above proton balance equation Alkalinity is defined by equation (1) in molar scale as follows:

$$
[\mathrm{Alk}]=-\left[\mathrm{H}^{+}\right]+\left[\mathrm{HCO}_{3}^{-}\right]_{\mathrm{T}}+\mathrm{CO}_{3}{ }^{2-}{ }_{\mathrm{T}}+\mathrm{OH}_{\mathrm{T}}^{-}
$$

In fact, it is only necessary to know one mass parameter and $\mathrm{pH}$ to determine species concentrations. The inverse is true: if two mass parameters values are known, it is possible to determine $\mathrm{pH}$ provided dissociation constants are known.

In low ionic strength waters it can be assumed that molarity $=$ molality $=$ mole fraction. However, in high salinity waters these equalities cannot be made. In these waters, the determination of single ion activity coefficients is a problem because thermodynamically it is not possible to measure single ion activity coefficients. A further factor affecting activities of ions in saline waters is the formation of ion pairs between oppositely charged ions in solution. These ion pairs may have zero or positive or negative charge. It also affects the ionic strength of solution and solubility products. In general, most weak acid species (like the carbonate system) ion pair with the principal cations in high salinity waters; for instance, $\mathrm{Mg}^{2+}, \mathrm{Ca}^{2+}, \mathrm{Na}^{+}$and $\mathrm{K}^{+}$. However, invariably weak acid concentrations are very much less than cation concentrations. Consequently, cation - weak acid ion pairing has negligible effect on cation concentration but has a profound effect on weak acid concentrations.

Measured or observed $\mathrm{pH}$ in high salinity waters is also termed operational $\mathrm{pH}$ and is defined as [3]:

$\mathrm{pH}=-\log \left(\mathrm{H}^{+}\right)$op $=-\operatorname{logf\mathrm {H}^{+}}$ op $-\log \left[\mathrm{H}^{+}\right]$

and $\mathrm{fH}^{\circ} \mathrm{p}=\kappa \mathrm{fH}+$

where $\kappa=$ Residual Liquid Junction Potential effect which has a constant value for a particu- lar solution. This parameter is different from one and $\mathrm{pH}$ observed is no longer simply related to the molar concentration of hydrogen ion. Hence, $\mathrm{pHop}$ is different from true $\mathrm{pH}(\mathrm{pHt})$ of solution. The operational $\mathrm{pH}$ is linked to the true $\mathrm{pH}$ as follows:

$\mathrm{pHop}=-\log \kappa \mathrm{fH}^{+}\left[\mathrm{H}^{+}\right]=\mathrm{pHop}-\mathrm{p} \kappa$

Estimation of RLJP effects; i.e., determination of $\kappa$ requires the estimation of $\mathrm{fH}^{+}$[3]. However, k" (RLJP) can be determined theoretically and experimentally by applying the modified Gran titration procedure [10]. Functions developed by Gran in 1952 for the carbonate system of low ionic strength natural waters (ionic strength less than 0,1 ) allow to obtain with great accuracy the volume of strong acid added to the particular equivalence point although it is not possible to know $\mathrm{pH}$ value of this point. For each of the three equivalence points two linear functions can be formulated. When the linear fraction of each plot is extrapolated to a function value equal to zero, the corresponding value of the strong base added is equal to the necessary volume to titrate back to the equivalence point under research. This is the way to determine Alkalinity and Acidity or one of its forms.

Function F5BC can be applied to saline waters in order to obtain the apparent dissociation constants which incorporate the effects of Residual Liquid Junction Potential. Application of these constants for calculating saturation indexes of saline waters can determine quantitatively the amount of calcium carbonate precipitated (supersaturation) or dissolved (undersaturation). This determination allows the establishment of water treatment techniques to improve the water quality. Function F5BC also allows the determination of Acidity and Alkalinity of saline waters and incorporates activities effects and ion pairing formation.

\section{THEORY}

The development of F5BC function requires the development of First and Second Gran functions, F1x e F2x, respectively. This function 
is applied initially in the $\mathrm{pH}$ region $9.0 \leq \mathrm{pHop} \leq$ 9, 5 (where op refers to operational or measured $\mathrm{pH}$ value) and its development is given by:

\section{NOTATION}

(i) Alkalinity and Acidity forms:

- Total Alkalinity or Alkalinity:

Alk

- Bicarbonate or Phenolphthalein Alkalinity:

$\mathrm{AlcHCO}_{3}$

- Total Acidity or Acidity:

Ac

- Bicarbonate Acidity or $\mathrm{CO}_{2}$ Acidity:

$\mathrm{AcHCO}_{3}$

(ii) Volumes:

- Volume of strong acid required to the bicarbonate equivalence point or $\mathrm{pHe}_{2}$ (unknown volume): $\mathrm{v}_{2,} \mathrm{ml}$

- Volume of strong acid require to the $\mathrm{H}_{2} \mathrm{CO}_{3}$ * equivalence point or $\mathrm{pH}_{\mathrm{el}}$ (unknown value) $\mathrm{v} 1, \mathrm{ml}$

- Volume of strong base added to the carbonate equivalence point or $\mathrm{pHe}_{3}$ : $\quad \mathrm{v}_{3}, \mathrm{ml}$

- Initial volume of the solution under investigation: vo, ml

- Incremental volume of strong acid added: $\mathrm{v}_{\mathrm{x}}, \mathrm{ml}$

(iii) Titrants:

- Molar concentration of the strong acid added, $\mathrm{HCl}$ to $\mathrm{pHe}_{1}$ and $\mathrm{pHe}_{2}$ : ca, mol. $1^{-1}$

- Molar concentration of strong base added to $\mathrm{pH}$ $\mathrm{e}_{3:}$

$\mathrm{cb}, \mathrm{mol} \cdot 1^{-1}$

The development of F5BC function considers that initially in the $\mathrm{pH}$ range of titration, Acidity is given by:

$[\mathrm{Ac}]=\mathrm{v}_{3} \mathrm{cb} /\left\{\mathrm{vo}+\mathrm{v}_{\mathrm{x}}\right\}=\mathrm{v}_{3} \mathrm{cb} / \mathrm{vT}$

At some point " $\mathrm{x}$ " in the $\mathrm{pH}$ range of titration, Acidity and Bicarbonate Acidity are given by:

$[\mathrm{Ac}]_{\mathrm{x}}=\left\{\mathrm{v}_{3}-\mathrm{v}_{\mathrm{x}}\right\} \mathrm{cb} / \mathrm{vT}$

$$
\left[\mathrm{AcHCO}_{3}\right] \mathrm{x}=\left\{\mathrm{v}_{2}-\mathrm{v}_{\mathrm{x}}\right\} \mathrm{cb} . / \mathrm{vT}
$$

In this $\mathrm{pH}$ range, equations defining Acidity and Bicarbonate Acidity are approximated to:

$$
[\mathrm{Ac}]_{\mathrm{x}} \approx\left[\mathrm{HCO}_{3}-\right]
$$

$$
\left[\mathrm{AcHCO}_{3}\right]_{\mathrm{x}}=-\left[\mathrm{CO}_{3}^{2-}\right]
$$

Substituting the above equations into equations (9 and 10), respectively:

$\left[\mathrm{CO}_{3}{ }^{2-}\right]=\left\{\mathrm{v}_{\mathrm{x}}-\mathrm{v}_{2}\right\} \mathrm{cb} / \mathrm{vT}$

$$
\left[\mathrm{HCO}_{3}^{-}\right]=\left\{\mathrm{v}_{3}-\mathrm{vx}\right\} \mathrm{cb} / \mathrm{vT}
$$

From the definition of the second dissociation constant of the carbonate system:

$\left[\mathrm{HCO}_{3}^{-}\right] /\left[\mathrm{CO}_{3}{ }^{2-}\right]=\mathrm{k}_{2}^{\prime} /\left(\mathrm{H}^{+}\right)=\left\{\mathrm{v}_{3}-\mathrm{v}_{\mathrm{x}}\right\} /\left\{\mathrm{v}_{\mathrm{x}}-\mathrm{v}_{2}\right\}$

For natural waters with low ionic strength $(\mathrm{I} \leq 0,10)$, the measured or observed $\mathrm{pH}$ is the real or true $\mathrm{pH}$ of the solution and $\mathrm{F} 5 \mathrm{BC}$ function is given by:

$10^{\mathrm{pH}}\left\{\mathrm{v}_{\mathrm{x}}-\mathrm{v}_{2}\right\}=1 / \mathrm{fH} \mathrm{k}_{2}{ }_{2}\left\{\mathrm{v}_{3}-\mathrm{v}_{\mathrm{x}}\right\}=\mathrm{F} 5 \mathrm{BC}$

For high salinity waters, the effects of RLJP are taken into account and the observed $\mathrm{pH}$ is the $\mathrm{pH}$ read off from the $\mathrm{pH}-$ meter. In this case, function F5BC is defined as:

$10^{\mathrm{pHop}}\left\{\mathrm{v}_{\mathrm{x}}-\mathrm{v}_{2}\right\}=1 / \mathrm{fH}_{\mathrm{op}} \cdot \mathrm{k}_{2}{ }_{2}\left\{\mathrm{v}_{3}-\mathrm{v}_{\mathrm{x}\}}=1 / \mathrm{k}_{2 \mathrm{op}}^{\prime}\right.$
$\left\{\mathrm{v}_{3}-\mathrm{v}_{\mathrm{x}}\right\}=\mathrm{F} 5 \mathrm{BC}$

The plot of F5BC versus volume vx added shows a linear relationship with slope given by:

$\mathrm{D} 5=1 / \mathrm{k}_{2}{ }_{2} ; \mathrm{D}^{\prime} 5=1 / \mathrm{fHk}_{2} ; \mathrm{D}^{\prime \prime} 5=1 / \mathrm{k}_{2 \mathrm{a}}$

where, $\mathrm{k}_{2 a \mathrm{p}}=$ second apparent dissociation constant for saline waters.

The extrapolation of the F5BC function to the zero abscises axis gives $v x=v_{3}$ (see Figure 1 below). Acidity is determined as follows:

$$
\mathrm{A}_{\mathrm{c}}=\mathrm{v}_{3}-\mathrm{v}_{\mathrm{x}} \mathrm{cb} / \mathrm{v}_{\mathrm{T}} \times 50 \times 10^{3}\left(\mathrm{mg} / \mathrm{L} \mathrm{CaCO}_{3}\right)
$$




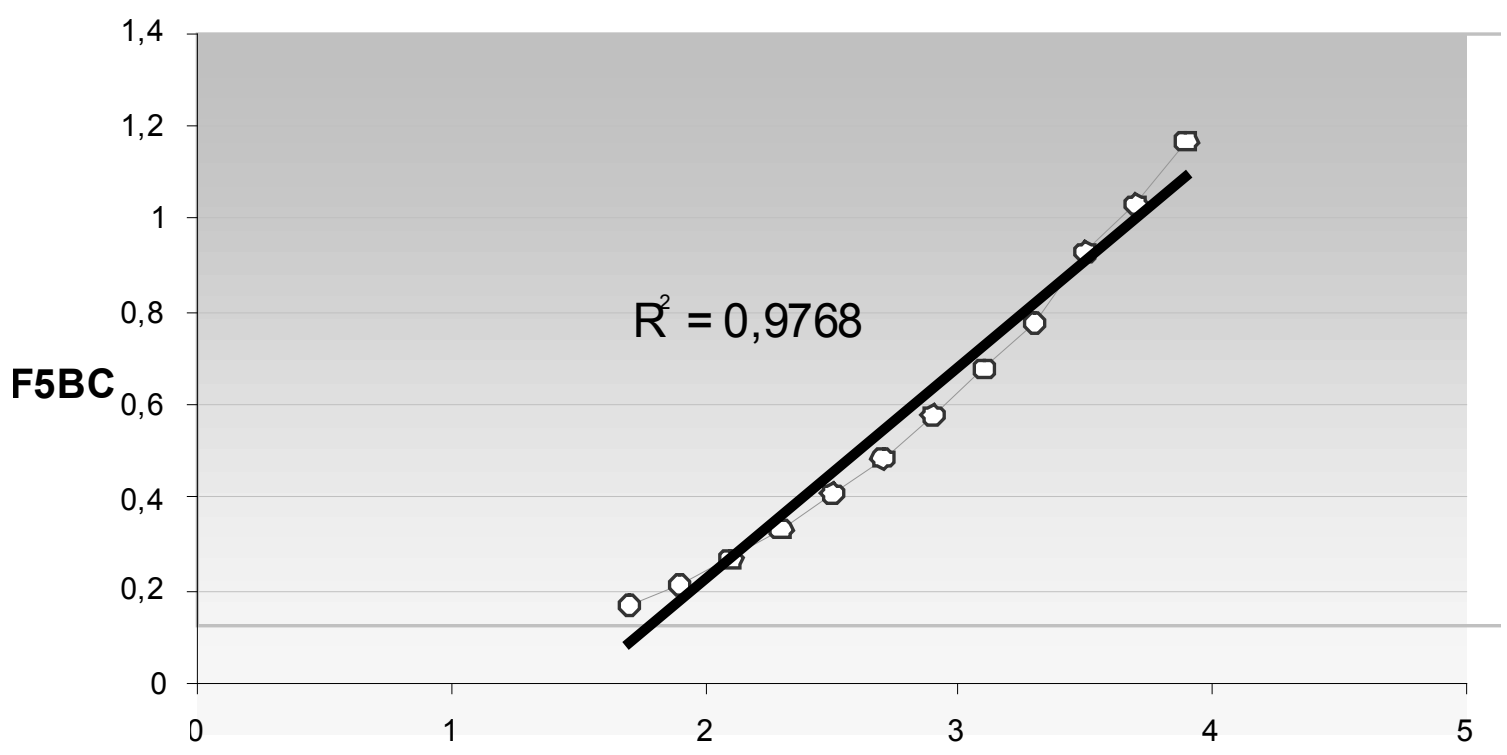

\section{o F5BCx10exp-10}

\section{Added volume, vx (ml)}

Figure 1. F5BC function versus volume of added titrant, $\mathrm{ml}$.

The apparatus used in the F5BC titration of test solution is shown in Figure 2 and are described as follows: A reactor consisting of a perspex cylinder of known volume. The cover of this reactor is slightly concave to aid the removal of air bubbles prior to the commencement of the experiment. At the center of the cover is a long Perspex pressure regulating outlet tube with a diameter of $3 \mathrm{~mm}$ that has three functions: (i) it provides a means of removing air bubbles from the reactor prior to commencing a titration; (ii) it maintains a constant pressure within the reactor during a titration, and (iii) it minimizes the possibility of $\mathrm{CO}_{2}$ exchange between the test solution and the atmosphere. The cover of the reactor is fitted also with three rubber sealed ringed apertures to locate (i) a dropping pipette feed from the piston burette, (ii) a $\mathrm{pH}$ electrode and (iii) a thermometer. The head of the dropping pipette has a very fine aperture which is curved slightly to prevent acid diffusion during an experiment. The electrometric measurements are carried out with a digital high precision $\mathrm{pH}$ meter with an input impedance greater than $10^{12} \mathrm{ohm}$ in combination with the solid state, drift free amplifier. The $\mathrm{pH}$ meter displays the $\mathrm{pH}$ to three decimal places. The titration procedure is the following: To initiate an experiment, first the reactor is filled with the test solution and air bubbles are removed by depressing the plunger shown in Figure 2 below. The reactor is then submerged into a constant temperature water bath which is maintained at $(25 \pm 0,1){ }^{\circ} \mathrm{C}$. Calibration of the electrode is carried out just prior to an experiment using buffer solution of 7,10 and 9,25 at

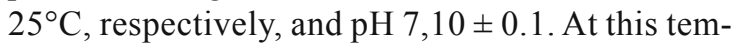
perature, constant increments $(0,5 \mathrm{ml})$ of strong base $(\mathrm{NaOH})$ with a precisely known molarity are added until the $\mathrm{pH}=9,0$. Then more increments of $\mathrm{NaOH}(0,2 \mathrm{ml})$ are added until $\mathrm{pH}$ reaches $\mathrm{pH}$ $=9,5$. After each increment of titrant added, the solution is stirred for 2 minutes with a magnetic stirrer. The $\mathrm{pH}$ reading is noted once the digital display of the $\mathrm{pH}$ meter reaches a constant value. After each addition of titrant, the plunger in the reactor is withdrawn slightly to maintain a constant liquid level in the outlet tube. In this way the system can accommodate volume changes and still remain essentially isolated from the atmosphere. 


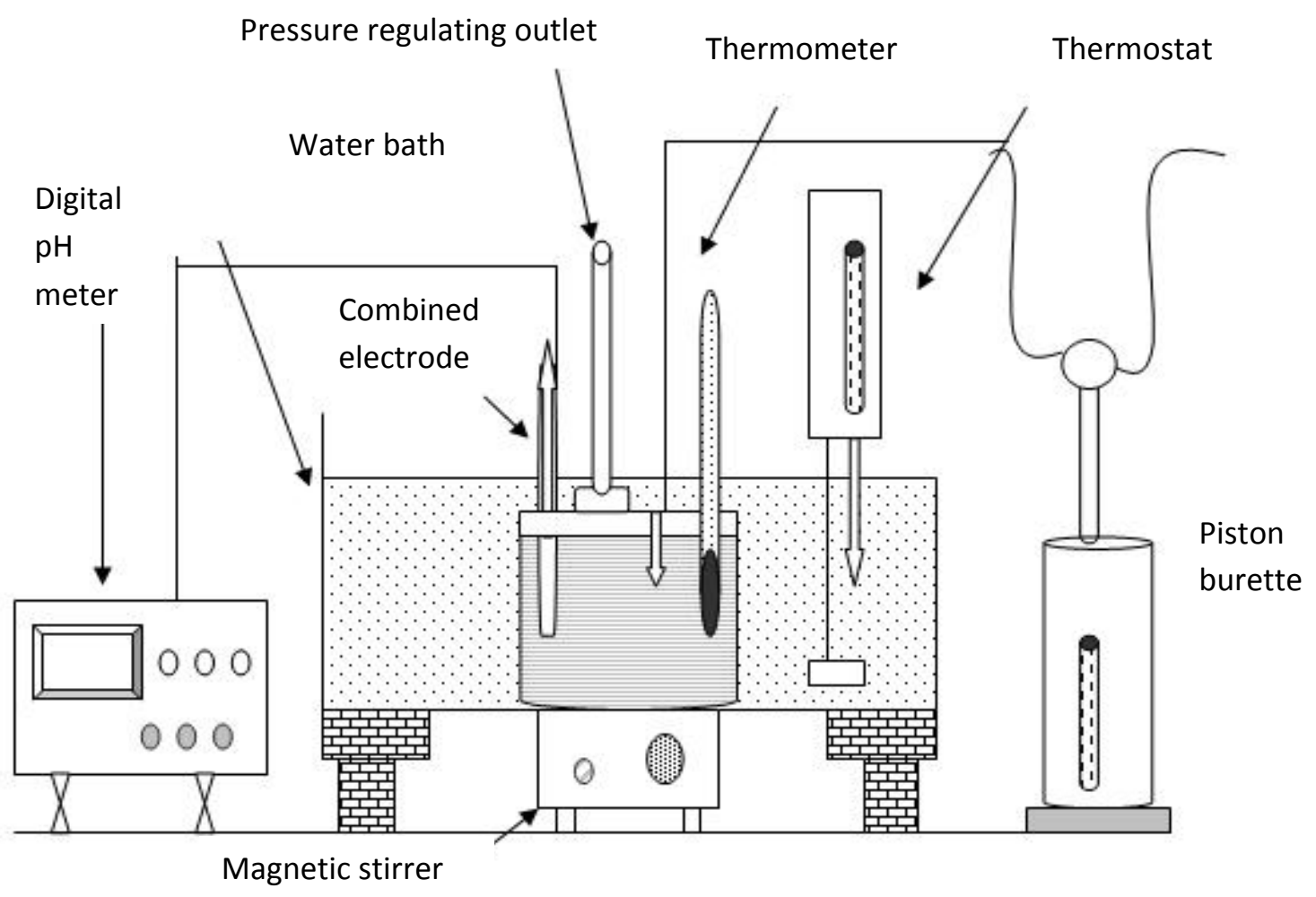

Figure 2. Apparatus used for the development of F5BC function.

\section{F5BC APPLICATIONS}

\section{1 - Selection of Samples}

In order to test $\mathrm{F} 5 \mathrm{BC}$ function it was used as sample the water of a small reservoir (see Figure 3 ) in Pocinhos, Paraiba state which is also referred as sample AsP. In all experiments the parameters ionic strength and temperature were maintained constants. Sample "AsP" has Total Dissolved Solids; TDS of $3000 \mathrm{mg} / \mathrm{L}$ and chloride concentration of $1100 \mathrm{mg} / \mathrm{L}$. 


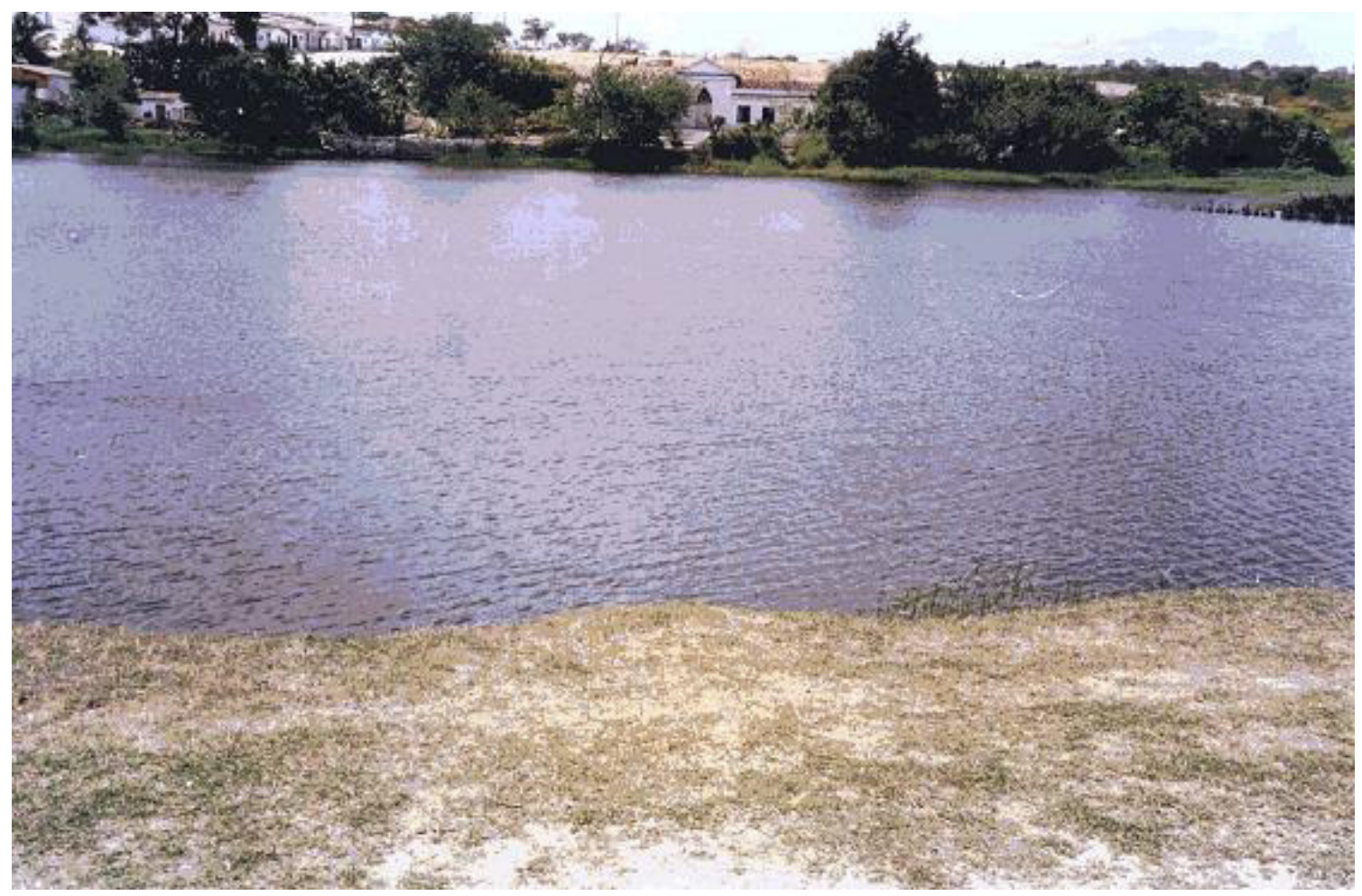

Figure 3. Pocinhos reservoir located in the semi - arid region of Paraiba state in Brazil.

\section{2 - Experimental Results}

In the development of $\mathrm{F} 5 \mathrm{BC}$ function are obtained some data of F1x and F2x modified Gran functions that allows the determination of Alkalinity and first dissociation constant of the carbonate system. Alkalinity is determined as follows:

For $F 1 x=0$ then $v 1=14,292 \mathrm{ml}$, the significance level is $R^{2}=0,99954$ for standard deviation of 0,00425 ; the operational activity coefficient for hydrogen is $f H o p=0,9630$ and Alkalinity is Alk =14, $292 \times 0$, 095/450. Therefore, Alkalinity is given by: Alk $(A s P)=3,02 \times 10^{-3}$ mol. $1^{-1}$ or $\mathrm{Alk}=151 \mathrm{mg} / \mathrm{L} \mathrm{CaCO}_{3}$.

For this water, theoretical Alkalinity is 2, $324 \times 10^{-3}$ moles. $\mathrm{L}^{-1}$ or $116.20 \mathrm{mg} / \mathrm{L} \mathrm{CaCO}_{3}$. Similarly the Acidity of sample AsP is calculated from equation (18) by using the volume of strong base added to the carbonate equivalence point; i.e., volume v3 (ml).

The second apparent dissociation constant for saline waters, k"2ap is obtained by applying $\mathrm{F} 5 \mathrm{BC}$ function and mixed titration in the $\mathrm{pH}$ range
$3,00 \leq \mathrm{pHop} \leq 9,5$. Results were submitted to linear regression technique and are shown in Tables 1 and 2 , respectively. 
Table 1. $\mathrm{pH}$ values obtained by titration with $\mathrm{F} 5 \mathrm{BC}$ function in $\mathrm{pH}$ range $3.00 \leq \mathrm{pHop} \leq 6,35$ for saline water asP1.

\begin{tabular}{cccc}
\hline \multicolumn{5}{c}{ Initial data: vo $=450.00 \mathrm{ml} ; \mathrm{ca}=0,10 \mathrm{M} \mathrm{HCl} ; \mathrm{T}=25^{\circ} \mathrm{C}$} \\
\hline $\mathrm{Vx}(\mathrm{ml})$ & $\mathrm{pHop}$ & $\mathrm{Vx}(\mathrm{ml})$ & $\mathrm{pHop}$ \\
- & - & 14,6 & 4,06 \\
- & - & 14,8 & 3,94 \\
- & - & 15,0 & 3,82 \\
6,4 & 6,35 & 15,2 & 3,72 \\
6,6 & 6,32 & 15,4 & 3,64 \\
6,8 & 6,30 & 15,6 & 3,57 \\
7,0 & 6,27 & 15,8 & 3,51 \\
7,2 & 6,25 & 16,0 & 3,46 \\
7,4 & 6,22 & 16,2 & 3,41 \\
7,6 & 6,20 & 16,4 & 3,37 \\
7,8 & 6,17 & 16,6 & 3,33 \\
8,0 & 6,14 & 16,8 & 3,29 \\
8,2 & 6,12 & 17,0 & 3,26 \\
8,4 & 6,09 & 17,2 & 3,23 \\
8,6 & 6,04 & 17,4 & 3,20 \\
8,8 & 6,02 & 17,6 & 3,17 \\
9,0 & 5,99 & 17,8 & 3,14 \\
9,2 & 5,97 & 18,0 & 3,12 \\
9,4 & 5,94 & 18,2 & 3,10 \\
\hline
\end{tabular}


Table 2. Parameters results used for determining Alkalinity and apparent dissociation constants of saline water from Pocinhos reservoir or asP sample.

\begin{tabular}{|c|c|c|}
\hline FunCTION/ParAMETERS & SALINE WATER “asP1" & SALINE WATER "ASP2" \\
\hline $\mathrm{F} 1 \mathrm{x}$ & $\mathrm{N}=24, \mathrm{R}^{2}=99,95 \%$ & $\mathrm{~N}=22, \mathrm{R}^{2}=98,56 \%$ \\
\hline Slope D'1 & 0,0963 & 0,1011 \\
\hline Activity coefficient fHop & 0,963 & 1,010 \\
\hline Standard deviation, dp & 0,00425 & \\
\hline Volume v1 (ml) & 14,29 & 15,75 \\
\hline Alk $\left(\mathrm{mg} / \mathrm{LCaCO}_{3}\right)$ & 151 & 166,25 \\
\hline 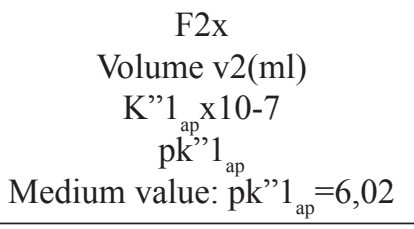 & $\begin{array}{c}\mathrm{N}=16 ; \mathrm{R}^{2}=99,78 \% \\
0,39 \\
6,13 \\
5,81\end{array}$ & $\begin{array}{c}\mathrm{N}=16 ; \mathrm{R}^{2}=99,79 \% \\
1,21 \\
6,21 \\
6,23\end{array}$ \\
\hline $\begin{array}{c}\text { F5BC } \\
\mathrm{a} 5 \times 10^{10}\end{array}$ & $\mathrm{~N}=29 ; \mathrm{R}^{2}=98,17 \%$ & $\mathrm{~N}=22 ; \mathrm{R}^{2}=98,56 \%$ \\
\hline dpa $\times 10^{10}$ & 1,5932 & $-1,6817$ \\
\hline $\mathrm{b} 5 \times 10^{10}$ & 0,0112 & 0,0109 \\
\hline $\operatorname{dpbx} 10^{10}$ & 0,4405 & 0,4452 \\
\hline Volume v3(ml) & 0,0165 & 0,0171 \\
\hline $\mathrm{K}^{\prime \prime 2}$ ap x $10^{-10}$ & 3,62 & 3,78 \\
\hline pk“2ap & 2,3574 & 2,2239 \\
\hline Medium value: $\mathrm{pk}{ }^{*}{ }_{\text {ap }}=9,64$ & 9,63 & 9,65 \\
\hline
\end{tabular}

$\mathrm{N}=$ number of data; $\mathrm{R}^{2}=$ significance level; $\mathrm{dp}=$ standard deviation, $\mathrm{k}$ "1ap e $\mathrm{k}$ "2ap = first and second apparent dissociation constant for saline waters, respectively.

\section{DISCUSSION AND CONCLUSIONS}

The errors in the estimation of Alkalinity and Acidity or one of its forms are generally attributed to the following factors: i) The $\mathrm{pH}$ reading in the $\mathrm{pH}$ meter do not show when the inflexion point is achieved; (ii) Depending on the buffer capacity of the titration endpoint, some small errors in the estimation of the equivalence point under investigation will give rise to severe errors in the measurements of parameters in aqueous phase.

Some external effects in the determination of equivalence points of the carbonate system were analyzed by Loewenthal and Marais (1986) as follows: (a) Increase in ionic strength and temperature of the aqueous solution modify the bicarbonate equivalence point and the carbonate equivalence point. However do not affect the $\mathrm{CO}_{2}$ equivalence point; (b) Any change in some carbonic species of the aqueous solution modifies also the Total Carbonate Species Concentration. This variation is negligible for $\mathrm{pHe} 2$. However, the $\mathrm{pHe} 1$ and $\mathrm{pHe} 3$ equivalence points are affected. Consequently, when determining Alkalinity ( $\mathrm{pHe} 1$ equivalence point) it is convenient to use a closed reactor to avoid changes in $\mathrm{CT}$ due to a possible increase in $\mathrm{CO}_{2}$ and (c) The exchange between $\mathrm{CO}_{2}$ and environmental air and ionic species in solution affects $\mathrm{pHe} 1$ causing a $\mathrm{pH}$ depression due to loss of $\mathrm{CO}_{2}$. For $\mathrm{pHe} 3$ there will be absorption of $\mathrm{CO}_{2}$ and, hence, $\mathrm{pH}$ of the endpoint titration will be depressed. No effect is observed in $\mathrm{pHe} 2$.

With regard to this investigation, the precipitation/ dissolution rate of calcium carbonate affects not only pHe1 (if calcium carbonate is in water there will be dissolution and, hence, the $\mathrm{pH}$ of the titration endpoint is depressed as well as $\mathrm{pHe} 3$ ) but also the final $\mathrm{pHe}$ which is diminished. 
Therefore for saline waters and hard waters the pHe1 endpoint will be strongly affected.

The use of F5BC function avoids this inconvenience. As to the estimation of dissociation constants, F5BC function has the advantage to include the influence of several factors such as Residual Liquid Junction Potential in pH electrometric measurements and electrometric measurement in terms of activity coefficients determination. This function also gives an accurate determination of the volume of strong base added to the equivalence point under investigation although this point is not known.

Resumo: Medições de parâmetros expressos em termos de espécies carbônicas tais como Alcalinidade e Acidez de águas Salinas não analisam a influencia de parâmetros externos tais como Concentração de Espécies Carbônicas livre e associada, formação de pares iônicos e Potencial de Residual de Junção Líquida em medições de pH. Este artigo mostra o desenvolvimento da função titulométrica F5BC com base nas titulações desenvolvidas por Gran (1952) para o sistema carbonatado de águas naturais. Para uso prático, amostras de água salina do açude de Pocinhos, PB foram submetidas à titulação e análise de regressão linear. Os resultados mostraram que a função F5BC compreende a determinação das funções tipo Gran F1x e F2x, respectivamente, para a obtenção de Alcalinidade e de Acidez sem conhecer "a priori" o ponto final da titulação. A função F5BC permite também a determinação da Primeira e da Segunda Constante Aparente de Dissociação do sistema carbonatado de águas salinas e de alta força iônica.

Palavras - chave: Águas Salinas; Alcalinidade; Constantes de Dissociação.

\section{REFERENCES}

[1] APHA, Am. Publ. Health Assoc., Standard Methods for the Examination of Water and Wastewater, USA, 2000.

[2] Araújo, L.M.L., A Determinação da Alcalinidade Total de Águas Naturais a $25^{\circ} \mathrm{C}, \mathrm{M}$. Sc. Thesis, Federal University of Campina Grande, 1984.

[3] Cavalcanti, B. F., Residual Liquid Junction Potentials in Binary Chloride Systems, M.Sc. Thesis, University of Cape Town, South Africa , 1981.

[4] Cavalcanti, B.F., Influence of Temperature and Ionic Strength on the First Dissociation Constant of the Carbonic System in Natural Waters, I SIBESA, In: Anais ABES/ANDIS, Vol.2, Tomo I, RJ, 1992, .256 - 272.

[5] Friend, J.F.C. and Loewenthal, R.E., Chemical conditioning of low and medium salinity Waters, Stasoft Version 3, 0, Water Research Commission Report, Pretoria, 1992, 80p.

[6] Gran, G., Determination of the Equivalent Point in Potentiometric Titration, Part II, Analyst, V.77,1952, p.661 -672 .

[7] Laraque, A., Estudo e Previsão da Qualidade da Água de Açudes no Nordeste Semi - Árido Brasileiro, Relatório SUDENE/DPG/PRW, Convênio ORSTOM, SUDENE, Recife, PEE, 1989, 95p.

[8] Liesching, P, Loewenthal, R.E. and Marais, G.v.R., Ion Pairing Determination in High Salinity Waters, Water Research Report, UCT, South Africa, 1979.

[9] Loewenthal, R.E. and Marais, G.v.R., Carbonate Chemistry of Aquatic Systems: Theory and Application, Ann Arbor Science, Michigan, USA, 1976.
[10] Loewenthal, R.E., Wiechers, H.N.S. and Marais, G.v.R., Softening and Stabilization of Municipal Waters, Water Com. Report., Pretoria, South Africa, 1986.

[11] Santos, P.G., Determinação da Primeira Constante Aparente de Dissociação de Águas de Alta Força Iônica á $25^{\circ} \mathrm{C}$, M.Sc. Thesis, UFPB, Campina Grande, PB, 1983.

[12] Stumm, W. and Morgan J., Aquatic Chemistry, Wiley Interscience, N.Y., USA, 1980, 780p. 